\title{
'De klinisch psycholoog is geen consigliere'
}

\section{$\mathbf{m}$ de verspreiding van Covid-19 tegen te gaan, is iedereen sinds 1 december 2020 verplicht om in openbare binnenruim-}

tes een mondkapje te dragen. Verschillende mensen zijn daar ongelukkig mee. Een aantal van hen komt in verzet. Het meest zichtbaar zijn de botte weigeraars: 'dat maak ik zelf wel uit', en 'knappe jongen die mij tegenhoudt'. Meer subtiel verzet loopt via de dokter. Men vraagt de arts om een verklaring dat een mondkapje voor deze patiënt 'medisch onverantwoord is'. Patiënten vragen ook aan ggz-behandelaars om dergelijke verklaringen af te geven. Het dragen van een mondkapje kan blijkbaar ook psychisch te belastend zijn. Het NIP vermeldt op haar website dat ggz-behandelaars zelf 'professioneel moeten inschatten' of zij aan zo'n verzoek willen meewerken.

Ik moest aan rechtspsycholoog wijlen professor Willem Wagenaar denken. Als actief thuissporter luister ik tijdens mijn dagelijkse routines op mijn roei-, cross- en hometrainer dikwijls naar hoorcolleges. Zo hoorde ik jaren geleden zijn college 'Psychologie in de rechtszaal'. Wagenaar stelt daarin dat psychologen als getuige-deskundige voor een rechter hun uitspraken wetenschappelijk moeten onderbouwen, en dat zij daarbij dus niet kunnen volstaan met anekdotiek en klinische observaties. De getuige-deskundige psycholoog moet zichzelf voortdurend afvragen of hij de volgende vraag van een rechter bevredigend kan beantwoorden: 'Getuige-deskundige, welke ondersteuning biedt uw wetenschap voor wat $u$ zojuist heeft betoogd?' Of woorden van gelijke strekking. Wagenaars wijze woorden waren voor mij altijd een belangrijke leidraad wanneer mij werd gevraagd om verklaringen, aanbevelingen of verzoeken te schrijven ten aanzien van de beperkingen en mogelijkheden van mijn patiënten.

Ik miste die leidraad in de NIP-stellingname over het afgeven van 'mondkapjesverklaringen'. Op basis van welke wetenschappelijke kennis kan een psycholoog verklaren dat zijn patiënt geestelijk te veel zal lijden onder een verplicht mondkapje? Het lijkt mij een lastige vraag. Sterker nog, mij schoot een mogelijke vervolgvraag van de rechter te binnen: 'Indien uw patiënt zo bang is om een mondkapje te dragen, waarom behandelt $u$ dan niet die angst, maar schrijft $u$ een aanbeveling tot ontheffing uit'?

De Landelijke Huisartsen Vereniging (LHV) liet meteen weten dat huisartsen geen 'mondkapjesverklaring' mogen afgeven omdat dit oneigenlijke elementen in de dokter-patiëntrelatie zou introduceren. Voor de klinisch psycholoog behoort hetzelfde te gelden: behandel je patiënt met de middelen die jouw wetenschap je aanreikt en treedt daar niet buiten. Dat geldt ook voor het afgeven van verklaringen waar de patiënt zelf om vraagt. Een klinisch psycholoog is tenslotte geen 'consigliere'. 